American Journal of Economics and Business Administration 1 (2): 182-193, 2009

ISSN 1945-5488

(C) 2009 Science Publications

\title{
An Exploration of the Organizational Culture in the International Business Relationships and Conflicts Era
}

\author{
${ }^{1}$ José G. Vargas-Hernández and ${ }^{2}$ Mohammad Reza Noruzi \\ ${ }^{1}$ Department of Marketing and International Business, \\ University Center for Economic and Administrative Sciences U of G, \\ Peripherals Norte 799 Building G-306, Zapopan, Jalisco CP 45,100, Mexico \\ ${ }^{2}$ Executive Master Business Administration, Islamic Azad University, Bonab, Iran
}

\begin{abstract}
Problem statement: The purpose is to analyze the organizational culture notion in relationships of co-operation in international business and management era. Approach: Public policies of government can strengthen or weaken the fiduciary culture. A political institution may be a good predictor of a quality constitution that prevents wasteful conflict among elites. Results: Also conflict between a firm, the community, new social movements and the role of government where the external political and social networks of the firm, mainly governmental agents and political actors, who play an important role will be discussed. Conclusion: Also facilitators to understand the repercussions of the inter-relationships between corporate cultural norms and practices and the community cultural norms and practices will be studied.
\end{abstract}

Key words: Organizational culture, conflict, relationships, co-operation

\section{INTRODUCTION}

Most scholars would not argue that organizational culture is a source of competitive advantage for firms $^{[5,82,85,86]}$.

In a rapidly changing environment, organizations constantly change goals and seemingly confront corporate cultural conflicts. We know hierarchical structure and cultural institutions are components of organizations ${ }^{[21]}$ so Understanding the culture in which a conflict occurs may clarify the assumptions, values and norms that reflect the intentions or motive of how the things are done ${ }^{[22]}$. The opposed values in two different economic, social, political or cultural systems are regarded as conflicting. Culture is an ideological and political arena ${ }^{[35]}$ where takes place competition over determination of meanings and contestation of weak groups who resist the imposition of meanings.

Culture as an ideological and political factors lies in the basic structure of economic and social organization and relations in "continual competition over the determination of meaning" an intensely "contested area where the weak groups attempt to resist the imposition of cultural norms and other symbolic values which bear the imprints of the dominant groups" ${ }^{,[13]}$. Economic growth may be the result of an institutional complementarity with the right balance between pro-society culture and private initiative driven by self interest. The economic history confirms that self-interest is the superior driving force to pro-society culture.

Identifying organizational culture dimensions: O'Reilly et al. ${ }^{[45,76]}$ developed an organizational culture profile using the Q-sort method on 54 value statements obtained through an extensive literature review. They identified seven dimensions of organizational culture, including innovation, outcome orientation and respect for people, team orientation, stability, aggressiveness and attention to detail. Denison and Mishra ${ }^{[77]}$ identified three dimensions of culture: Adaptability of the organization, mission/goal orientation and employee involvement and participation. In his extensive study of organizational culture, Hofstede ${ }^{[26,78]}$ reported six dimensions: Process oriented Vs results oriented, employee oriented Vs job oriented, parochial Vs professional, open system Vs closed system, lose control Vs tight control and normative Vs pragmatic. However, he did not relate these dimensions to either antecedents or consequences of organizational culture.

Corresponding Author: José G. Vargas-Hernández, Department of Marketing and International Business,

University Center for Economic and Administrative Sciences U of G,

Peripherals Norte 799 Building G-306, Zapopan, Jalisco CP 45,100, Mexico

Tel/Fax: +52(33) 3770 3343/ext 5097 
Cheng ${ }^{[79]}$ examined organizational culture values in Taiwan. His interview study revealed nine cultural dimensions, some being unique to the Taiwanese business context. Comparing his findings to Peters and Waterman's ${ }^{[80]}$ findings, he considered these to be emic (unique to Taiwan) dimensions: Uprightness and honesty, social responsibility, performance orientation and neighborhood harmony. To compare the differences in values between two generations of workers, $\mathrm{Liu}^{[81]}$ developed a framework of cultural values (i.e., harmony, loyalty, bureaucracy, equality and security) based on interviews and surveys.

Schein defined organizational culture as 'a pattern of basic assumptions that the group learned as it solved its problems of external adaptation and internal integration, that has worked well enough to be considered solid and, therefore, to be taught to new members as the correct way to perceive, think and feel in relation to those problems, ${ }^{[82,86]}$. In accordance with this definition, values that enhance the organization's capacity for internal integration and external adaptation should be useful for the firm, including firms in contexts undergoing restructuring and facing major changes in legal, social and economic institutions, such as those in China. Guided by Schein's definition, Xin et $a l .{ }^{[83]}$ identified ten attributes of organizational culture in Chinese SOEs. Six dimensions relate to the internal integration function (employee development, harmony, leadership, pragmatism, employee contribution and fair rewards) and four dimensions to the external adaptation function (outcome orientation, customer orientation, future orientation and innovation ${ }^{[84]}$.

Cultural assimilation in globalization era: Firms as societies and communities have different cultures or ways of life. Cultural differences play a role in causing conflicts in business settings which can result in a reconfiguration of social and economic relations. Cultures of different societies have been characterized $^{[37]}$ by measuring the prevailing basic social values on key dimensions ${ }^{[53]}$.

While traditional communities and societies have more strong and differentiated cultures, modern societies have more fragmented and are becoming more homogeneous cultures, although it cannot said that they have a common culture ${ }^{[1]}$. On the interface of two cultures takes place considerable reciprocal borrowing and learning on the two different ways of doing things ushering in an evolutionary convergence. From the reciprocal borrowing and learning can follow an eventual integration of divergent cultural practices and values. However, a negative convergence of corporate cultures may be the cause of reciprocally influence each other and developing conflicts during the process of a controversial cultural assimilation.

More recently, academics renew the debate over the 'convergence-divergence' thesis in relation to the issues of corporate culture/corporate governance/management models ${ }^{[66]}$ and the debate on cultural assimilation. National cultures with individual autonomy and egalitarianism correlate positively with better firm's governance because they facilitate an effective balance of power. Uncertainty avoidance, power distance and masculine cultural values have a significant negative relationship as the necessary condition associated for a form of governance across countries, although the value systems may be biased towards Western values and culture centered on the balance of power in the high levels of corporate hierarchies $^{[9,11]}$ and negotiation processes ${ }^{[8]}$. The basic value system of Schwartz ${ }^{[53-55]}$ considers cognitive factors, such as egalitarianism but not altruism or selftranscendence, in a controversial cross-cultural economic analysis, thus missing the dominant structures of economic behaviors ${ }^{[37]}$. The major cultural value dimensions, hierarchical, collectivist, pro-self and individualist ${ }^{[70]}$ have a distinctive set of assumptions.

Cultural affects on economy: According to Mittelman $^{[30]}$, globalization is "a historical transformation in economy and cultural diversity". Globalization is the idea of making the world act like a huge country. Globalization affects this world and the people in this world in many ways. Globalization affects the economic status of a country. It has indeed weakened the position of poor countries and exposed poor people to harmful competition.

Globalization is the strategy of liberation that becomes an economic nightmare for the poor. The poor countries disintegrate and worsen via trade and investments. Even if the world co-operates and acts as one country, the richer always gets to say what happens. For example, United States is a country that is one of the richest in this world. They influence globalization to their own advantage, harming the economic and cultural issues of the rest of the world. They might be concerned about some countries, but not most of them. For example, the Saharan countries is mid-Africa is not getting any attention from the "giants" of this world. Poverty is increasing which proves that globalization has become a dominant factor in producing poverty. The effects of globalization leading to poverty maybe due to competition among different workers or foreign investment. Workers from different viewpoint of the world are different. If they compete against each other, surely the workers with 
more facilities, which are from the rich countries, will win the competition ${ }^{[19]}$.

The interplay of different ideological, socioeconomic and institutional orientations in a dynamic process of social and cultural forces within an organization may exchange cultural values, norms, traits, regulations and converge into a common hybrid, new, modern signified corporate culture.

Culture is no stranger to economics. Institutional economics $^{[67]}$ and new institutional economics ${ }^{[42]}$ take culture into economic analysis, although they differ with the main stream economics on the standing of cultural values. Cultural effects on economy have been carried out in innovation, efficiency, equity and objectives. There is a causal connection between cultural values and governance systems. Dimensions on perceived national cultural differences lead to a profile of nations in adherence to governance norms. Cultural values determine the economy in democratic countries where people have political rights ${ }^{[50]}$. Triandis ${ }^{[67]}$ marked the relationship between Hofstede's cultural values and economic growth.

\section{Organizational culture and conflicts in international} convergence and divergence: The conflict over the highest economic and political goals is one of the most impenetrable barriers to convergence and probably the most persistent among and within nations ${ }^{[31]}$. On the negative side of cultural convergence, socio economic systems can reciprocally 'contaminate' each other.

A hybrid convergence between different socioeconomic and cultural systems is a dynamic process that selects cultural values and institutions that are redefined an innovated which Berger ${ }^{[6]}$ posits as 'alternative cultural globalizations'. Mexican-born managers trained in United States, Britain or Canada's management schools are culturally hybrids who behave on the peripheries of two cultural entities of the Mexican way versus the Anglo Saxons way.

Convergence of culture may lead to cultural innovations. Cultural hybrids may be agents of cultural innovations in international business settings although they may be victimized by suspicion and distrusted. Studies on the contrasting influences of altruistic culture support the finding of a balance between the self-transcendence dimension and private innovative driving forces as a new insight into economic governance theory. Altruistic culture as an instrument is driven by philanthropy or the influence of social norms more than values compatible with social recognition as the cultural factor. In late medieval Europe, the culture of altruism was expected from officials in duties.
Norms and values of altruistic culture are determinants of economic governance and corruption. Corruption reflects a culture of low altruism among the civil service officials. Culture in corruption has two roles $^{[8]}$, with more variation in the propensity to punish corrupt behavior than in the propensity to engage in corrupt behavior across cultures, which indicate the different cultural factors, norms and values independently functioning in society. Behavior that has been inconsistent with culture might not be defended publicly and culture has been internalized to become a value.

Because democratic culture is not a sufficient determinant of democratization and collective action ${ }^{[63]}$ so political culture maybe less important than altruistic culture. The culture of checks and balances in a society $^{[44]}$ dictated by public interest bear the related culture of bureaucrats and politicians which is transformed into a set of presumptions, values, norms and rules to organize and manage governmental organizations and agencies.

Chan et al. ${ }^{[12]}$ call this dynamic process as evolutionary convergence. Conflict is the precondition that sets in motion the evolution of a new, integrated, fused, signified corporate culture. Convergent evolution draws cultural values of two or more societies closer together which may result in the loss of their distinct cultural identity and thus in identity crisis ${ }^{[75]}$. Cultures and cultural identity are increasingly fragmented and fractured subject to transformation across different practices and positions.

Corporate organizational culture and international relationships: The impact of culture in the corporate environment and its positive effects are becoming increasingly important. Human organizations are influenced by human behavior and cannot be simply and predictably added together. Culture is pervasive variable affecting business. Culture arises endogenously through shared experience, is path dependent and idiosyncratic. Corporative culture is a characteristic of organizations, not of individuals ${ }^{[25]}$. Much of corporate culture research is questionnaires administered to large numbers of members of a few organizations ${ }^{[14,28,45,56,76]}$ or ethnographic observation of interactions in organizations ${ }^{44,58,60]}$ making it difficult to draw firm conclusions.

There is a great deal of debate these days about corporate culture and its impact on the long term performance of a firm. Culture developed in an organization through joint experience over long periods of time, allow an organization's members to coordinate activity tacitly without having to reach agreement 
explicitly in every instance. Two or more cultures can merge trough processes of cultural amalgamation into a single new culture containing old elements and new elements of all cultures involved ${ }^{[30]}$. With all the partnerships and restructuring going on in organizations these days, clashes between different cultures are inevitable. An analysis of corporate cultures is a critical tool in the evaluation of future performance and governance.

Firms are driven by their own kind of corporative culture deliberately expressed through a variety of forms. The impact of culture in the corporate environment is becoming increasingly important and the impact of corporate culture on an economic, social and political environment can have profound implications in real world markets. Corporate culture has received less attention from economic approach than from organizational researchers. On an economic approach, culture is an efficiency-improving asset in which firms can invest ${ }^{[24]}$. Culture rules are socially understood solutions to multiple equilibria of the uncertainties of behavior $^{[33]}$.

Conflicts in international relationships: Conflict as a fundamental phenomenon arises in all organizations that can potentially threaten core organizational processes. Organizations develop distinct conflict cultures. There are some factors that might predict conflict culture strength in organizations. Conflict cultures have a potential impact on organizational outcomes and influence on task and interpersonal conflict and health outcomes. Conflict cultures are facilitated through both top-down processes such as leadership and organizational structure and bottom-up processes such as the role of individual level attributes, such as personality, demographics and values ${ }^{[34]}$. Topdown factors affect the development of dominating, passive-aggressive, avoidant and collaborative conflict cultures.

At the crossroads of change, corporate culture in Mexican organizations is one of the main causes of conflict. Conflicts between firms and communities are commonly perceived as the effect of cultural differences ${ }^{[69]}$ can occur at structural level due to the socio-economic, politico-ideological and legal set-up of the firm and at the individual level due to attitudes, personality, mind-set and other idiosyncrasies of the proprietors, managers and inhabitants of communities. Conflicts can be functional or dysfunctional, or both, to organizations.

Language constitutes a large part of the shared understanding held by organizational members ${ }^{[17,56,60]}$ playing an important role of conflict in corporate culture. Researchers have found the connection between culture and group's language which reflects group members' shared understanding and representation of the world $^{[4,17,27,36,56]}$. Shared understanding among organizational members usually comes about through shared experience and process of socialization.

The soft area of corporate culture has been neglected by most organizations by blending the needs of business and diversity of the work place which has left behind as long as there are results. Corporate cultural practices of collective punishments and rewards and open or closed communication directly promulgate social and political external networks of the firm to benefit or damage the welfare of an entire community. These relationships are mediated by the respective corporate and community cultural norms of cooperation and conflict. Differences in more elaborate forms of corporate culture result in potentially greater conflict.

Conflicting cultures may cause inefficiencies in corporate alliances with communities, nongovernmental organizations, new social movements, governments and other important actors of civil society and government. Cultural conflict often plays a role in producing merger failure. Differences in culture between two organizations are largely responsible for failures in performance ${ }^{[68]}$. In handling cultural conflict, informal rule is the dominant type of enforcement in Japan while legal enforcement is the more accepted way in the $\mathrm{US}^{[10]}$.

Weber and Camerer ${ }^{[70]}$ experimented allowing subjects in firms to develop a culture during the period of merging of two firms and found that subjects overestimate the performance of the merged firm and attribute the decrease in performance to members of the other firm rather than to conflictive situations created by conflicting culture. Conflicts are unexpected because the difficulties to measure differences in culture. These researchers found that cultural conflict contribute to the failure of corporate mergers and suggests that cultural conflict and coordination failures between firms are underestimated. It also can be hypothesized the cooperation failures due to cultural conflicts between firms, communities, new social movements and governments are most likely to fuel conflicts. Weber and Camerer ${ }^{[70]}$ found evidence of conflict and mistaken blame arising from the differences in culture, pointing to a possible source for the high turnover rate following mergers.

People living in communities do not give up their old ways or blend to a firm's corporate culture with different values, customs and histories without a struggle. 
The issue of the need to coexist with other economic agents and social and political actors despite the cultural divergence deals with far better across businesses, communities, different levels of government, new social movements with different cultures to bridge the cultural divide formally or informally.

Culture and international business: Any theory of corporate culture frame values, beliefs and meanings that enable an organization to endure, adapt and transform itself are the primary source of motivated and coordinated activity ${ }^{[18]}$. Functionalists explain the persistence of corporate culture by analyzing the functionality of some elements that resolve cooperation and coordination problems and enhance economic efficiency. The functionalist approach to corporate culture try to understand the persistence of culture by isolating and examining elements from the standpoint of functionality such as how a particular firm's culture enhances co-operation or conflict relationships with other economic agents and social and political actors such as the community, new social movements and the different levels of government.

National cultures are linked to institutional structures of national business systems. The origins and evolution of institutions requires an understanding of cultural differences. International business has traditionally interpreted the term culture to mean national cultures exclusively and has emphasized differences among nations as a central, unique focus of the field. This focus is particularly evident in international business research distilling national cultures into a small number of universal dimensions. Hofstede ${ }^{[26,78]}$ has warned against applying national culture dimensions to subnational levels. This research has long been criticized for oversimplifying complex cultures, generalizing from a limited number of firms, assuming that culture and social structures are static and ignoring within country heterogeneity.

When national average characteristics are used to predict or explain the behavior of individuals, groups of firms, the relatively low amount of variance explained by the cultural values in many studies underscores the existence of the many other forces besides national culture which determine the behavior and attitudes of individuals in societies ${ }^{[32]}$. Culture is considered to be a general shared social understanding, resulting in commonly held assumptions and views of the world among organizational members ${ }^{[56,60,71]}$ Rousseau 1990. Hall and Soskice ${ }^{[23]}$ conceive culture is of "a set of shared understandings and available 'strategies for action".
Culture and corporate culture: Cultures are more than language, dress and food customs. Cultural groups may share race, ethnicity, or nationality, but they also arise from cleavages of generation, socioeconomic class, sexual orientation, ability and disability, political and religious affiliation, language and gender.

Lazear $^{[36]}$ defines culture as the shared expectations and patterns of behavior among individuals. Culture are "codes" path dependent developed by organizations to help coordinate activities ${ }^{[3]}$ in an efficient manner and facilitates efficient economic exchange ${ }^{[36]}$. Cremer ${ }^{[17]}$ defines culture as "the part of the stock of knowledge that is shared by a substantial portion of the employees of the firm, but not by the general population from which they are drawn". The organization responds to outside messages in a coordinated manner, which is less costly when the stock of shared knowledge is greater, because of less time needed for communication.

Also, Schein ${ }^{[82,86]}$ defined culture as: A pattern of shared basic assumptions that the group earned as it solved its problems of external adoption and internal integration that has worked well enough to be considered valid and, therefore, to be taught to new members as the correct way to perceive, think and feel in relation to those problems. Corporate culture is defined as the pattern of shared values that define appropriate attitudes and behaviors and establish what is important for organizational members ${ }^{[25,44,49,59]}$.

Corporate culture explains differences, unintended misperceptions and conflicts considered as irrational and incomprehensible behaviors of organizational members in terms of their unconscious basic assumptions taken for granted. However, there is nothing irrational about cultural basic assumptions which evolve because they are precisely adaptive and rational and act as the glue that binds the culture together.

Corporate culture is one of the contextual and process variables that may influence diverse group functioning in addition to culture. Contextual factors of organizations influence diverse group behavior ${ }^{[72]}$. Basic assumptions in culture evolve within a context and operate below awareness affecting decisionmaking processes in situations outside the context in which had evolved and for which they are maladaptive as Schein ${ }^{[82,86]}$ explains: "If we understand the dynamics of culture, we will be less likely to be puzzled, irritated and anxious when we encounter the unfamiliar and seemingly irrational behavior of people in organizations and we will have a deeper understanding not only of why various groups of people or organizations can be so different but also why it is so hard to change them". 
Corporate culture summarizes the collective characteristics, norms, behaviors and values of an organization's members which are different insofar members differ ${ }^{[34]}$. Chan et al. ${ }^{[12]}$ describe corporate culture referring to the values, beliefs and principles that serve as a foundation for an organization's management system and the set of management practices and forms of behavior that both exemplify and reinforce those basic principles. The principles, practices and forms of behavior have meanings for the members of an organization and represent strategies of adaptation and change while interacting with its environment.

Corporate culture is shared socially constructed and is transmitted across organizational generations and contains multiple layers ${ }^{[28,41,46,52,59,82,86]}$. Corporate culture involves a 'process of identity construction during the ongoing interaction between the culture in question and its environment ${ }^{[49]}$.

Multiple backgrounds and characteristics shape individuals' and organizations' identities, perceptions, attitudes and behaviors that strongly influence the operations of firms. The corporate culture is described by the environment, values, heroes, rites and rituals and the cultural network ${ }^{[61]}$.

Leadership is a key antecedent to corporate culture originated by the organizational founder and reinforced by the vision and actions of the organization's senior leaders ${ }^{[46,60]}$. Schein has said that:

"If we are leaders who are trying to get our organizations to become more effective in the face of severe environmental pressures, we are sometimes amazed at the degree to which individuals and groups in the organization will continue to behave in obviously ineffective ways, often threatening the very survival of the organization, ${ }^{\text {, }[82,86]}$

High centralization is positively linked to the development of passive-defensive corporate cultures which are characterized by norms that allow little control over the employees' work lives ${ }^{[16]}$.

Many conceptions and measures of corporate culture focus on broad values, norms and assumptions as they relate to many aspects of organizing and more specifically namely the shared assumptions, values and norms that develop in organizations for managing conflict. As Wilson ${ }^{[74]}$ recounts "The predispositions of members, the technology of the organization and the situational imperatives with which the agency must cope tend to give the organization a distinctive way of seeing and responding to the world". There is a relationship between the corporate culture and the conflict resolution communication approach used within an organization.

Corporate culture and conflicts in co-operation between a firm, community, new social movements and the role of government: The discussion of cultural basis of conflict management advance arguments for the existence of organizational conflict cultures. The concept of cultural conflict applies also to organizational subcultures and in conflict cultures, subcultures may exist ${ }^{[40,64]}$. Schein ${ }^{[82,86]}$ recognizes that subculture conflict to is related to group membership, when he states that "Ambiguity and conflict also result from the fact that each of us belongs to many groups so that what we bring to any given group is influenced by the assumptions that are appropriate to our other group"

Intergroup conflict constantly threatens the ability of both domestic and global firms to operate efficiently, cooperatively and fairly. The degree of conflict management varies according to the competitive or cooperative nature of group conflict management styles. Organizations develop norms for whether conflict is managed actively in a prosocial, cooperative manner or passively in an antisocial, competitive manner ${ }^{[92]}$.

The normative way to manage conflict is referred to as distinct conflict cultures which minimize individual variation in conflict management styles. In management of organizations, norms are critical for organizational functioning. Kolb and Putnam ${ }^{[34]}$ argued that conflict norms tend to arise from the corporate culture. Conflict management norms develop and constrain individual variation in larger organizational units. Norms are linked to corporate cultures as compared to formal and officially sanctioned roles and procedures found in grievance systems.

Context factors, such as industry, community context and societal culture shape the development of corporate culture and the formation of distinct conflict cultures. Corporate culture is one of the potential contextual factors that may influence group processes $^{[65,72]}$. The contextual factors reduce or facilitate the main effects of group diversity on intragroup conflict. Corporate culture moderates group diversity and intra-group conflict ${ }^{[13]}$. There is empirical evidence that group diversity can lead to high intragroup conflict ${ }^{[29,48]}$.

Organizations can manage diversity by emphasizing some particular cultural values to improve overall group functioning. Chuang et al. ${ }^{[15]}$ consider that the relationship between group diversity and intragroup conflict can be moderated by the strength 
and the content of corporate culture. They proposed that corporate culture value congruence reduce the positive effects of visible diversity on tasked-related conflict and functional background diversity on relationship conflict. Both organizational cultural value congruence and culture content moderate the relationships between diversity and intra-group conflict. Corporate culture value congruence focuses on the degree of value similarity among organizational members and does not address the content of cultural values.

Chuang et al. ${ }^{[15]}$ propose that organizational cultural intensity and content have a direct impact on intra-group conflict and moderate the relationship between group diversity and intra-group conflict, depending on the degree of value congruence and the value content shared among group members. They argue that both corporate culture intensity and content have an impact on the work group functioning of diverse groups, depending on the degree of intensity and the cultural content embedded in the members in the workplace.

Diverse groups tend to have high degree of task related and relationship conflict ${ }^{[29,48]}$. Diverse groups embedded within the corporate culture shared among members may reinforce or suppress group or individual values to shape group processes. A diverse group embedded within an organization with high cultural value congruence may have some effects and take advantage of the benefits of diversity on intra-group conflict, which may be facilitated by corporate culture and are contingent on the degree of cultural value congruence and cultural content shared among group members.

Tsui et al. ${ }^{[65]}$ contended that consistent corporate culture as a social category and as an attractive psychological group provides social identity for individuals in such a way that it is likely to supersede other bases of an individual's social identity. The notion that culture serves a powerful social control function limits the range of acceptable behavior which restricts individual differences in organizations is critical in many theories of organizations. Corporate culture is a social control system that shapes individual's behavior ${ }^{[44]}$ and has significant influence on the functioning of diverse groups.

The social and political conflict has arisen because the main actors, the firm and the community have different objectives, organization structures and cultures. The results of the conflict between the corporate culture of the firm and the community culture can be analyzed under a dialectic process of conflict, as a precondition for even a brutal collision or confrontation, between two different sets of values. Out of the dialectic of competing cultural values in a cultural dynamics of reciprocal learning and adaptation, a positive convergent hybrid corporate culture emerges. The social dynamics of human interactions is a developmental process of action and reaction or thesis and antitheses that emphasizes change and stresses a state of 'dynamic equilibrium'. Cultural convergence in business and communities settings may take a more static and unilinear forms without necessarily undergoing any fundamental qualitative change in relationships between them ${ }^{[12]}$, which can be in a state of dynamic equilibrium until newly emerged conflicts tip the balance in favor of either party.

A firm that practices Western corporate culture type and an aggressive business strategy in a Mexican traditional community encounters resistance.

Corporate culture of parent firms located in North American countries like United States and Canada is characterized according to Chan et al. ${ }^{[12]}$ by Western liberalism, procedural justice, transparency, individual accountability, self motivation, loyalty, creativity, role interchangeability, meritocracy, non-discrimination and so on. Western corporate culture enhances entrepreneurs' preoccupation with techno-structure, science, rationality, rationalism and profit-motive, thus ignoring the human side of production. But at the same time the Western corporate culture have some attractive attributes of Western management as humanism, equality, meritocracy, autonomy, creativity and respect.

Any analysis of cultural differences and conflicts is by necessity an analysis of circumstances under a dialectic perspective. Foreign managers of a foreign firm are eager to operationalize and institutionalize their vision of Western corporate culture in total disregard of the local cultural peculiarities and socialpsychological and cultural elements specific to the economic environment of Mexico are essential ingredients of social conflicts and is bound to run into trouble. According to the theory of "fields", or organized social spaces ${ }^{[7,20]}$, collective actors produce a local culture that defines social relationships of cooperation and conflict to legitimate the power structure within a system of dominance.

There is not a common ground such as cultural similarity to use a problem-solving strategy instead of a legalistic strategy ${ }^{[38]}$.

Cultural globalization in the Mexican context demonstrates clearly just how such a resistance on the part of a traditional rural community may come about. The community is over-protective of its own traditional values that emphasize the ethnocentric collective interests, the strong feelings of nationalism and encourages communication between individuals and 
with other new social movements in subdued style of expression and not mindful of the exactness of the information received, but always disclosed to the whole community, often misinterpreting the cultural differences, misunderstanding and widening the socialpsychological distance. In highly collectivistic and uncertainty avoidance cultures, conflict avoidant corporate cultures might be more effective. Passiveaggressive conflict cultures manage conflicts through passive resistance under the assumptions that competition and antisocial behavior are likely to develop in highly centralized, formalized and bureaucratic organizational structures with authoritarian or abusive leaders.

The level of development of culture affected by the patterns of interaction between firms, communities, new social movements and the role of government is an important issue that requires further research.

Williamson ${ }^{[73]}$ contends that higher priority of national goals and justice requires a pro-society culture. Pro-society value supporting a fiduciary culture for government officials and citizens is a driving force shaping characteristics and setting the limit of economic development. Cultural values have effects on economic development. Pro-society value and fiduciary culture are determinants of economic development.

\section{CONCLUSION}

In a rapidly changing environment, with global economy orientation and driven by modern western business practices, conflict is present in almost all corporate cultures and the way it is resolved. The San Pedro case reflects this Mexican corporate culture reality where culture conflict is being played out in the corporate arena at several levels and at the interplay of relationships of co-operation and conflict between the firm, community, new social movements and the different levels of government. It is corporate culture conflict being played out in an environment of global changes sweeping every sphere of the market, societies and the states, from government, nongovernmental organizations and communities, the manifestation is evident in all arenas.

The firm and the foreign investors are preoccupied and have a proactive attitude self-motivated to achieve higher profits, encourage communication with government officials with informational accuracy and preciseness. The managers of the firm keep the results of negotiations with other parties and government official confidential. Dominating conflict cultures are characterized by norms and shared perceptions for conflict management that sustain an active, open competition and antisocial normative behaviors involving confrontation to win conflicts with little concern and respect for others' feelings and points of view and There is no one-size-fits-all approach to conflict resolution, since culture is always a factor. Cultural fluency is therefore a core competency for those who intervene in conflicts or simply want to function more effectively in their own lives and situations. Cultural fluency involves recognizing and acting respectfully from the knowledge that communication, ways of naming, framing and taming conflict, approaches to meaning-making and identities and roles vary across cultures ${ }^{[39]}$.

Culture is an essential part of conflict and conflict resolution. Cultures are like underground rivers that run through our lives and relationships, giving us messages that shape our perceptions, attributions, judgments and ideas of self and other. Though cultures are powerful, they are often unconscious, influencing conflict and attempts to resolve conflict in imperceptible ways.

A strong fiduciary culture is necessary for laying the foundations of society ${ }^{[2]}$. The fiduciary culture is driven either by pro-society values and norms is determinant of the accountability that mitigates the personal opportunism associated with the discretion of government officials. The fiduciary culture may be driven by either the strong norm of reciprocal altruism or altruistic value. The fiduciary culture has an influence on public hierarchy.

Best practice institutions can not be a substitute for fiduciary culture, which are more flexible, noncontextual and do not take into account complicated constraints across societies $^{[51]}$. With a certain degree of pro-social culture, strengthening government officials' fiduciary culture and citizens sacrificing self-benefit for public goods ${ }^{[43]}$ transaction costs of politics can be minimized. The pro-society value and fiduciary culture explain the dynamics of the interaction among institutional capitals and influences, contributing to economic governance systems across countries ${ }^{[10]}$.

Conflicts between the firm and the community arise out of each agent's emphasis on its own rights and as a result of failures in communication between them. The argument over cultural differences between the corporate culture of the firm and the cultural values of the community, the new social movements and government couched in nationalistic terms is a highly emotionally charged issue that exacerbates the relationships resulting in a social conflict. Altruistic value evidently support or impede the governance demonstrating the causal linkage between cultural values and economic performance ${ }^{[37]}$. 


\section{REFERENCES}

1. Abercrombie, N. et al., 2000. The Penguin Dictionary of Sociology. 4th Edn., Penguin Books, London.

2. Acemoglu, D. and J. Simon, 2003. Unbundling institutions. NBER Working Paper. http//www.nber.org/papers/w9934

3. Arrow, K.A., 1974. The Limits of Organization. WW Norton and Company, New York.

4. Barley, S.R., 1983. Semiotics and the study of occupational and organizational cultures. Admin. Sci. Q., 28: 393-413.

5. Barney, J.B., 1986. "Organizational culture: Can it be a source of sustained competitive advantage? Acad. Manage. Rev., 11: 656-65.

6. Berger, P.L., 2002. Introduction: The Cultural Dynamics of Globalization. In: Many Globalizations: Cultural Diversity in the Contemporary World, Berger, P.L. and S.P. Huntington (Eds.). Oxford University Press, Oxford, pp: 1-16.

7. Bourdieu, P., 1977. Outline of a Theory of Practice, Cambridge University Press, Cambridge, UK., ISBN: 13: 9780521291644.

8. Burkardt, N. and B.L. Lamb, 1997. Power distribution in complex environmental negotiations: Does balance matter? J. Public Admin. Res. Theor., 7: 247-75.

9. Cameron L.A., A. Chaudhuri, N. Erkal and L. Gangaharan, 2005. Do attitudes towards corruption differ across culture? Experimental evidences from Australia, India, Indonesia and Singapore. http://www.ssrn.com/abstract $=778464$

10. Chaithanakij, S., 2007. Does the American corporate governance model contribute to economic optimality? A Game-Theoric Analysis. Corporate Governance Seminar, Faculty of Economics.

http://www.econ.tu.ac.th/doc/seminar/123/seminar _aug27_surasak_us.pdf

11. Thammasat, U., S. Chaithanakij, 2007. The Culture of economic governance: Toward a model of economic

prosperity.http://papers.ssrn.com/sol3/papers.cfm?a bstract_id $=1277868$

12. Chaithanakij, S., 2006. The determinants for success and failure of corporate governance system: The analysis of Thai corporate governance through the lens of three-pillared framework. Doctor of Philosophy Dissertation, Thammasat University, Bangkok, (In Thai). http://www.econ.tu.ac.th/doc/seminar/123/seminar _aug27_surasak_japan.pdf
13. Chan, K.B., V. Luk and G.X. Wang, 2005. Conflict and innovation in international joint ventures: Toward a new signified corporate culture or 'alternative globalization' in China. Asia Pacif. Bus. Rev., 11: 461-482

14. Chatman, J.A., J.T. Polzer, S.G. Barsade and M.A. Neale, 1998. Being different yet feeling similar: The influence of demographic composition and corporate culture on work process and outcomes. Admin. Sci. Q., 43: 749-80.

15. Chatterjee, S., M.H. Lubatkin, D.M. Schweiger and Y. Weber, 1992. Cultural differences and shareholder value in related mergers: Linking equity and human capital. Strat. Manage. J., 13: 319-334.

16. Chuang, Y.T., R. Church and J. Zikic, 2004. Internal conflict, diversity management, corporate culture. corporate culture, group diversity and intra-group conflict. Team Perform. Manage., 10: 26-34.

17. Cooke, R.A. and J.L. Szumal, 2000. Using the Corporate Culture Inventory to Understand the Operating Cultures of Organizations. In: Handbook of Corporate Culture and Climate, Ashkanasy, N.M., C.P.M. Wilderom and M.F. Peterson (Eds.). Sage, Thousand Oaks, CA., pp: 147-162.

18. Cremer, J., 1993. Corporate culture and shared knowledge. Ind. Corporate Change, 2: 351-386.

19. Denison, D.R., 1990. Corporate culture and organizational effectiveness. John Wiley and Sons ISBN: 10: 047180021X, pp: 267.

20. Economic Culture Globalization, 2007. First 1500 characters of The Effects of Globalization on the Economy. http://www.123helpme.com

21. Fligstein, N., 2001. The architecture of markets: An economic sociology of twenty-first-century capitalist societies. Princeton University Press, Princeton, New Jersey. http://press.princeton.edu/titles/7206.html

22. Greif, A., 2005. Institutions and the Path to the Modern Economy: Lessons from Medieval Trade. Cambridge University Press. http://www.amazon.com/Institutions-Path-ModernEconomy-Political/dp/0521671345

23. Greif, A., 2007. The impact of administrative power on political and economic development: Toward political economy of implementation. http://papers.ssrn.com//abstract_id=1004394

24. Hall, P.A. and D. Soskice, 2001. An introduction to Varieties of Capitalism. In: Varieties of Capitalism: The Institutional Foundations of Comparative Advantage, Hall, P.A. and D. Soskice (Eds.). Oxford University Press, Oxford, UK., pp: 1-68. 
25. Hermalin, B.E., 2001. Economics and Corporate Culture. In: Handbook of Organizational Culture and Climate, Cooper, S., S. Cartwright and P.C. Early (Eds.). John Wiley and Sons, Chichester, UK.

26. Hofstede, G., 1998. Attitudes, values and corporate culture: Disentangling the concepts. Org. Stud., 19: 477-492.

27. Hofstede, G., 1984. Cultures Consequences: International Differences in Work-Related Values. Sage Publications, Beverly Hills, CA.

28. Hofstede, G., B. Neuijen, D.D. Ohayv and G. Sanders, 1990. Measuring organizational cultures: A qualitative and quantitative study across twenty cases. Admin. Sci. Q., 35: 286-316.

29. Jehn, K.A., G.B. Northcraft and M.A. Neale, 1999. Why differences make a difference: A field study of diversity, conflict and performance in workgroups. Admin. Sci. Q., 44: 741-63.

30. Mittelman, J.H., 2004. The effects of globalization on the economy.

http://www.123helpme.com/preview.asp?id=63738

31. Johnson, A.G., 2000. The Blackwell Dictionary of Sociology. 2nd Edn., Blackwell Publishers, Oxford.

32. Kerr, C., 1983. The Future of Industrial Societies: Convergence of Continuing Diversity? Harvard University Press, Cambridge, MA.

33. Kirkman, B.L., K.B. Lowe and C.B. Gibson, 2006. A quarter Century of culture's Consequences. A review of empirical research incorporating Hofstede's cultural values Framework. J. Int. Bus. Stud., 37: 285-320.

34. Kolb, D.M. and L.L. Putnam, 1992. Introduction: The Dialectics of Disputing. In: Hidden Conflict in Organizations, Kolb, D. and J.M. Bartunek (Eds.). Sage Publications, pp: 1-31.

35. Kreps, D.M., 1990. Corporate Culture and Economic Theory. In: Perspectives on Positive Political Economy, Alt, J.E. and K.A. Shepsle (Eds.). Cambridge University Press, Cambridge, UK.

36. Kozlowski, S.W.J. and K.J. Klein, 2000. A Multilevel Approach to Theory and Research in Organizations: Contextual, Temporal and Emergent Processes. In: Multilevel Theory, Research and Methods in Organizations. Foundations, Extensions and New Directions, Klein, K.J. and S.W.J. Kozlowski (Eds.). JosseyBass, San Francisco, CA., pp: 3-90.

37. Kuper, A. and J. Kuper, 1996. The Social Science Encyclopedia. 2nd Edn., Routledge, London, pp: 160 .
38. Lazear, E.P., 1999. Culture and language. J. Political Econ., 107: 95-126.

39. Licht, A.N., C. Goldschmidt and S.H. Schwatz, 2004. Cultural rules: The foundation of the rule of law and the other norms of governance. University of California Boalt Hall School of Law Working Paper.

http://www.law.berkeley.edu/centers/bclbe/Courses /216.4lepsych.papers/amir.pdf

40. Lin, X. and R. Germain, 1998. Sustaining satisfactory joint venture relationships: The role of conflict resolution strategy. J. Int. Bus. Stud., 1: 179-196.

41. LeBaron M., 2003. Culture and conflict, knowledge base essay. http://www.beyondintractability.org

42. Martin, J., 1992. Cultures in Organizations: Three Perspectives. 13th Edn., Oxford University Press, New York.

43. Mohan, M.L., $1993 . \quad$ Organizational Communication and Cultural Vision: Approaches for Analysis. State University of New York Press, Albany, New Jersey ISBN: 10: 0-7914-1537-6.

44. North and Weingast 1989. Constitutions and commitment: evolution of institutions governing public choice in 17 th century England. J. Econ. History, XLIX: 803.

45. North, D.C., 1990. Institutions, Institutional Change and Economic Performance. Cambridge University Press, Cambridge, ISBN: 978-0-19507164-1.

46. North, D.C., 1990. A transaction cost theory of politics. J. Theor. Polit., 2: 355-367.

47. O'Reilly, C. and J. Chatman, 1996. Culture as Social Control: Corporations, Cults and Commitment. In: Research in Organizational Behavior, Shaw, B. and L. Cummings (Eds.), Vol. 18, JAI Press, pp: 157-200.

48. Ostroff, C., A.J. Kinicki and M.M. Tamkins, 2003. Organizational Climate and Culture. In: Handbook of Psychology: Industrial and Organizational Psychology, Borman, W.C., D.R. Ilgen and R.J. Klimoski (Eds.), Vol. 12, John Wiley and Sons, Hoboken, New Jersey, pp: 565-593.

49. Ott, S.J., 1989. The Corporate Culture Perspective. 2nd Edn., The Porsey Press, Chicago, IL.

50. Pelled, L.H., K.M. Eisenhardt and K.R. Xin, 1999. Exploring the black box: An analysis of work group diversity, conflict and performance. Admin. Sci. Q., 44: 1-28.

51. Peverelli, P., 2002. Cognitive Space: A Social Cognitive Approach to Sino-Western Cooperation. Eburon, Delft. 
52. Pryor, F.L., 2007. Culture and economic systems. Am. J. Econ. Sociol., 66: 817-55.

53. Rodrik, D., 2008. Second-best institutions. Am. Econ. Rev., 98: 100-104.

54. Rowlinson, M. and S. Proctor, 1999. Corporate culture and business history. Org. Stud., 20: 369-396.

55. Schwartz, S.H., 1999. Cultural value differences and some implications for work. Applied Psychol.: Int. Rev., 48: 23-47.

56. Schwartz, S.H., 1992. Universals in content and structure of values: Theoretical advances and empirical tests in 20 countries. Adv. Exp. Soc. Psychol., 25: 1-65.

57. Schwartz, S.H., 1994. Beyond Individualism/Collectivism: New Cultural Dimension of Values. In: Individualism/Collectivism: Theory, Method and Applications, Kim, U., H.C. Triandis, C. Kâgitçibasi, S.C. Choi and G. Yoon (Eds.). Sage Publications, Thousands Oaks, USA., pp: 85-122.

58. Schall, M.S., 1983. A communication-rules approach to organizational culture. Admin. Sci. Q., 28: 557-581.

59. Schein, E.H., 2000. Sense and Nonsense about Culture and Climate. In: Handbook of Organizational Culture and Climate, Ashkanasy, N.M., C.P.M. Wilderom and M.F. Peterson (Eds.). Sage, Thousand Oaks, CA., pp: 23-30.

60. Schein, E.H., 1992. Corporate Culture and Leadership: A Dynamic View. 2nd Edn., JosseyBass, San Francisco.

61. Schein, E.H., 1990. Organizational culture. Am. Psych., 45: 109-119.

62. Schein, E., 1985. Corporate Culture and Leadership. Jossey-Bass, San Francisco, CA.

63. Schein, E.H., 1983. The role of the founder in creating corporate culture. Org. Dyn., 20: 13-28.

64. Schnell, J., 1985. Corporate culture and conflict resolution: A study of a Greek lettered social organization.

http://www.eric.ed.gov/ERICWebPortal/contentdel ivery/servlet/ERICServlet?accno=ED273522

65. Smith, L.T. and M. Col James, 1998. Air force culture and cohesion. Aeros. Power J., 12: 40-53.

66. Teorell, J. and A. Hadenius, 2006. Democracy without democratic values: A rejoinder to welzel and inglehart. Stud. Comparat. Int. Dev. 41: 95-111.

67. Triandis, Harry C. 1984. Toward a Psychological Theory of Economic Growth. Int. J. Psychol., 19: 79-95.

68. Trice, H.M. and J.M. Beyer, 1993. The Cultures of Work Organizations. 1st Edn., Prentice Hall, Englewood Cliffs, New Jersey, ISBN: 1-58113930-6.
69. Tsui, A.S., T.D. Egan and K.R. Xin, 1995. Diversity in Organizations: Lessons from Demography Research. In: Diversity in Organizations: New Perspectives for a Changing Workplace, Chemers, M.M., S. Oskamp and M.A. Costanzo (Eds.). Sage, Thousand Oaks, CA., pp: 191-219.

70. Eric, V.D., D. de Cremer and M.J.J. Handgraaf, 2004. Social value orientations and the strategic use of fairness in ultimatum bargaining.J. Exp. Soc. Psychol., 40: 697-707.

71. Van den Berghe, L., 2002. Corporate Governance in a Globalizing World: Convergence or Divergence?" A European Perspective. Kluwer Academic Publishers, Norwell.

72. Veblen, T.B., 1898. Why is economics not an evolutionary science? Q. J. Econ., 12: 373-397.

73. Vlasic, B. and B. Stertz, 2000. Taken for a Ride: How Daimler-Benz Drove Off with Chrysler. 2nd Edn., William Morrow and Co., New York.

74. Wang, G.X., K.B. Chan and V. Luk, 2003. Conflict and its management in Sino-Foreign joint ventures: A review. David C. Lam Institute for East-West Studies" Working Paper Series, 10, pp: 34.

75. Weber, R.A. and C.F. Camerer, 2003. Cultural conflict and merger failure: An experimental approach. Manage. Sci., 49: 400-415.

76. Wilkins, A.L. and W.G. Ouchi, 1983. Efficient cultures: Exploring the relationship between culture and organizational performance. Admin. Sci. Q., 28: 468-481.

77. Williams, K.Y. and C.A. O'Reilly, 1998. Demography and diversity in organizations: A review of 40 years of research. Res. Org. Behav., 20: 77-140.

78. Williamson, O.E., 1999. Public and private hierarchies: A transaction cost economics perspective. J. Law Econ. Org., 15: 306-342.

79. Wilson, J.Q., 1989. Bureaucracy: What Government Agencies Do and Why They Do It. 2nd Edn., Basic Books Inc.

80. Yan, Y.X., 2002. Managed Globalization: State Power and Cultural Transition in China. In: Many Globalizations: Cultural Diversity in the Contemporary World, Berger, P. and S. Huntington (Eds.). Oxford University Press, Oxford, pp: 19-47.

81. O'Reilly, C.A., J.A. Chatman and D.F. Caldwell, 1991. People and organizational culture: A profile comparisons approach to assessing personorganization fit. Acad. Manage. J., 34: 487-516.

82. Denison, D.R. and A.H. Mishra, 1995. Toward a theory of organizational culture and effectiveness. Org. Sci., 6: 204-223. 
83. Hofstede, G., 1991. Cultures and Organizations: Software of the Mind. 2nd Edn., McGraw-Hill Book Company, Berkshire.

84. Cheng, B.S., 1990. Quantitative testing of organizational cultural values. J. Chinese Psychol., 33: 31-49.

85. Peters, T.J. and R.H. Waterman, 1982. In Search of Excellence. Harper and Row, New York, ISBN: 0060150424.

86. Liu, S., 2003. Cultures within culture: Unity and diversity of two generations of employees in stateowned enterprises. Hum. Relat., 56: 387-417.

87. Schein, E.H., 1992. Organizational Culture and Leadership. 2nd Edn., Jossey-Bass, San Francisco, CA.

88. Xin, K.R., A.S. Tsui, H. Wang, Z. Zhang and W. Chen, 2002. "Corporate Culture in Chinese State-Owned Enterprises: An Inductive Analysis of Dimensions and Influences. In: The Management of Enterprises in the People's Republic of China, Tsui, A.S. and C.M. Lau (Eds.). Kluwer Academic Press, Boston, MA., pp: 415-443.

89. Tsui, A.S., H. Wang1 and K.R. Xin, 2006. Organizational culture in China: An analysis of culture dimensions and culture types. Manage. Org. Rev., 2: 345-376.
90. Kotter, J.P. and J.L. Heskett, 1992. Corporate Culture and Performance. 2nd Edn., Free Press, New York,

91. Schein, E.H., 1992. Organizational Culture and Leadership. 2nd Edn., Jossey-Bass, San Francisco, CA.

http://www.fsc.yorku.ca/york/istheory/wiki/index.p hp/Organizational_culture_theory

92. Van de Vliert, E. and M.C. Euwema, 1994. Agreeableness and activeness as components of conflict behaviors. J. Personal. Soc. Psychol., 66, 674-687. 